\title{
我国の軽合金ダイキャストについて
}

\author{
三 浦 清 吉* \\ THE LIGHT METAL DIE CASTING IN JAPAN
}

(Received Jan 3I. I955)

\section{SEIKICHI MIURA}

ダイキャスト法は砂鋳物に比べると新しい方法である が、シエルモールド法、粉末治金法等の最近の精密鋳造 法に比較すると古い方法である。

此の方法が初めて試みられたのは1840年頃で、活字鋳 造機から考光出されたと謂われているから約 100 年以上 の歴史を持つている。然し、1900年の初期まではダイキ ヤスト法の確性が甚だ不安定であつたため、一般に利用 されることが少なく其の存在も認められなかつたようで ある。其の特性が認められ、各種の機械部品に使用せら れるようになつたのは近々 $20 \backsim 30$ 年以来のことで其の後 の発展は頗る目覚しいものがあり、最近のダイキャスト 製品は従来の種々な金属加工法を駆遂し、あらゆる分 野、即ち簡単な装飾品から重要機械部品にまで利用せら れるに至つたのである。

我国に於ても時期的なズレはあるが以上の傾向は同様 である。此れはダイキャスト法が我国に於て行われたの は明治の最終期が大正の初めとされているが、企業とし て初められたのは大正 6 年 (1917) であつてアメリカの それとは約70へ80年の開きがあり而も狭隃なる我国機械 工業の生産数量と多量生産を目標とするダイキャスト法 とは長い間合致しなかつたことに原因するものである。

ダイキャスト製品の不確実性による未発達はダイキャ スト業者自身の問題であつて、ダイキャスト機械の未発 達、ダイキャスト技術の未習得及びダイキャスト用諸合 金研究の不偖にあつた。

アルミニウム合金ダイキャストが初められたのはアメ リカに於て1.914年であり我国に於ては昭和の初期3へ4年

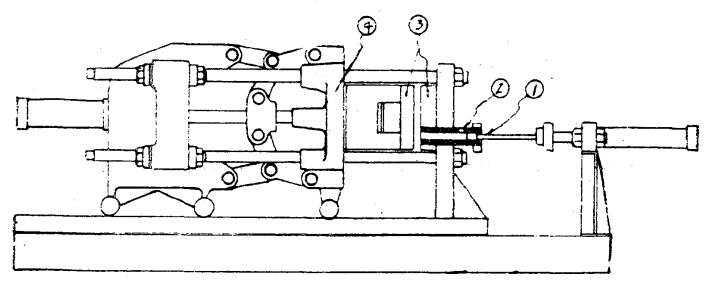

Cold Chamber Type Machine (合金熔解鉄鍋は機械と別に装置する)
(1) プランヂャー
(2) 注入 口

(3) 鋳

(4) 可”動 盤
(1930) 頃からである。銅合金のダイキャストも其の頃 より同時に行われている、此れはダイキャスト機械の発 達によるものである。

\section{ダイキャスト機械}

現在では亜鉛、錫、鉛基合金には Hot Chamber Type Machine (熱加圧室機械) を用い、アルミニウム、マグ ネシウム、銅基合金には Cold Chamber Type Machine (冷加圧室式機械) を用いるというのが常識とな つている。

之れは熔融温度の高いアルミニウム、マグネシウム、 銅合金ダイキャストに Hot Chamber Type Machine を使用すれば合金内に鉄の量が増加し合金の質を低下す るため Cold Chamber Type Machine を使用するので ある。又此の Cold Chamber Type Machine には機械 の構造上高圧力を使用する必要があり Hot Chamber Type Machine よりも圧入圧力を高め得られる。最近の Cold Chamber Type Machine は大抵、油圧力又は水 圧力を利用しており、単位圧力を 120 䏕 $/ \mathrm{cm}^{2}$ 以上の圧 力を使用する。句論人力、空気圧等を用いてもダイキャ スト製品は作り得られるが、質的に前者に劣るため、ダ イキャスト製品の確性が少なく重要機械部品としては不 適当である。之れは我国に於ても漸次ダイキャスト業者 も使用者側も認識し了解しつつあるところである。

1、2カ月前の或る外国雑誌の紹介によれば、マグネシ ウム合金ダイキャストにHot Chamber Type Machine

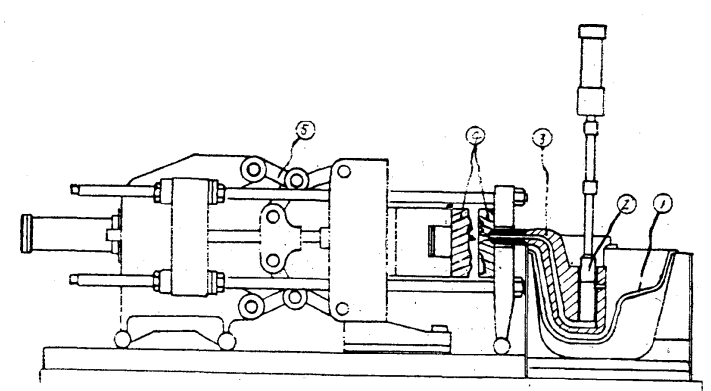

Hot Ghamber Type Machine
(1) 鉄
鍋
(3) グーズネック
(2) プランヂャー
(5) トグル型締メ機構

*田中ダイカスト株式会社取締役 
を使用することが出来るそうである。現在の Hot Chamber Type Machine に或る種の装置を施すことは勿論 である。これはマグネシウム合金はダイキャスト作業中 合金の酸化を極度にきらうという特殊条件もあるが、熔 解温度が殆んど同程度であるアルミニウム合金に比して 鉄を侵食する率が少ないために其れが可能なものと考兄 られる。近い将来に於て、ダイキャスト機械の庄入装置 の加熱部分に使用せられる鋳鉄、鋳鋼、及び特殊鋼等の 耐熱度が高められてアルミニウム合金ダイキャストにも Hot Chamber Type Machine が使用せられることにな ると思う。ダイキャスト業者としては高速度で生産性の 高い優れたアルミニウム合金用 Hot Chamber Type Die Casting Machine の出現を切望するものである。

次にダイキャスト法の重大なる特徴であるコスト低下 の目的のために機械の高速度化を図り極最近の機械は特 に輸入された諸外国の近代的機械は全て自動式機械であ ることは今後益々ダイキャストの利用範囲を増大するこ とになり、低コストのダイキャスト製品は諸機械、器具 の輸出に充分貢献することになるであろう。

\section{ダイキャスト用軽合金}

\section{アルミニウム基合金}

我国に於ける初期のダイキャストト用アルミニウム諸合 金は各社共まちまちであつたと思われるが、Si13;Cu4n $\mathrm{Si} 5$; のシルミン、ラウタールが主として用いられた。其

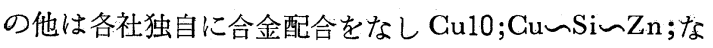
ど種々あつた。当社（田中ダイカスト）に於てはアルミ ニウム地金にはアルコア会社製程度 $99.3 \%$ の新地金を合 金して使用した。之れは国産アルミニウム地金の市販さ れるまで続いた。其の後航空規格中に軽合全ダイ鋳物規 格が決定され航空機用部品には一応適用され、各社共統 一し、一般機械部品にも使用されたが、第二次世界大戦 となり、アルミニウム地金の配給が統制され鋳物用とし ての新地金が配給中止となり、ダイキャスト業者は反対 したのであるが全面的に再生塊が配給せられるようにな つてダイキャスト製品の質は著しく粗悪化した。それと 同時に寸法精度の点に於ても又生産性の面に於ても甚だ しく低下し、ダイキャスト製品とは砂鋳物よりも多少寸 法精度が高く鋳肌も手を加えずに済む程度であり、值段 の高いものであるという感じを残した。此の事実は終戦 後 J E S 規格中にダイ鋳物用合金として規格付けられた ものの、成分不明のスクラップ材料を其儘使用したもの が多かつたため数年間はダイキャスト製品とは一時的間 に合わせのものであるから使用する材料も再生塊のみで 充分であるという考觉があつた。之れによつてアルミニ ウムダイキャスト製品の信用を失陮した例が多くあつ た。どんな成分の合金でもダイキャスト製品は出来るか らといつて材料面を等閑視することは絶対に許されない ことを強調して熄まない。

最近に於ては諸外国の主としてアメリカの文献その他 によりアルミニウム合金は非常に改良せられダイキャス
ト業者は各社共良心的な材料を使用するに至つているの で、戦前の製品に比べても決して劣らず優れたものを製 出している。鋳物の表面肌に於ても内部組織の完全さに よる物理的、機械的性質に於ても又寸法精度の高度化の 点に於ても過去の何れの時期にも見られない優れたもの となり世界的水準にまで到達した欠点のない鋳物を製出 し、以前の悪評を殆んど駆遂し使用者は安心してアルミ ニウムダイキャスト製品を使用している。

乍然、以上の傾向は A.S.T.M 規格の採用や特需関 係の仕事を引請けた会社に見受けられる処であつて、ダ イキャスト業者全部に完全に行わ机ているとは云い難い 状態である。近々学界、研究所等の権威者と官庁及びダ イキャスト業者の協力により J I S 規格として新にダイ 鋳物用アルミニウム合金規格が決定せられることである から今後は一定した合金がどの会社工場に於て子使用せ らるることになると思う。加之、日本軽金属株式会社及 び昭和電工株式会社に於て既にシルミン合金地金を市販 しているし尚前者からはラウタール系の合金も試販され 業界の反響を俟つて量産市販されることになつているか ら正規の規格配合を持つたアルミニウム諸合金が使用さ れ全面的にダイキャント製品の優秀性が確保され、さき に規格品として市販されている亜鉛基合金と共に益々其 の利用範囲が拡大されることを確信する。ダイキャスト 業界にとつて真に喜ばしい限りである。

A. S.T.M規格にはダイキャスト用アルミニウム合 金として11種類程規定されているが、我国に於てはがイ キャスト業者の設備しているアルミニウム用ダイキャス ト機械は殆んど Cold Chamber Type Machine である から一応数種類に統合し、其の後、学界、研究所、材料 会社及びダイキャスト会社等の研究による新合金を規格 に採用しては如何と考える。

今後は流動性のあるシルミン、含銅シルミン系のもの と鋳造性に難点はあるが耐食性のあるヒドロナリウム䒺 のものが相当進出して来る傾向があることをつけ加えて 置く。

\section{マグネシウム合金}

マグネシウム合金ダイキャストは昭和10年頃から各社 共研究に着手し昭和13 14年頃より航空機部品に使用し 実用化された。合金としてはAL10\%のものが使用された がダイキャスト部品为極一部の部品にのみ使用され、ア ルミニウム合金の如く全航的な部品にまで使用せられる には至らず而も終戦と同時に其の要求もなくなり、且つ 材料地金の点よりも全面的に中止されるようになつた。

最近はアメリカに於て航空機部品に限らず一般兵器、 光学機械、事務用機器等の一般機械部品に広く使用せら れているので、我国でも極最近になつて再び製作が開始 され各社共其の研究、製作に努力している。今後のマグ ネシウム合金ダイキャストは戦時中のものとは違つた意 味に於て相当広範囲に使用せられるであろう。前にも述 ベたように Hot Chamber Type Machine を使用してダ 
イキャスト製品を製作することになると製造コストも非 常に低廉となり、材料費毛西鉛、アルミニウムと比較の割 安であるから其の発展は大いに期待される。ただ材料受 理と防錆処理方法の合理化が一番問題となるであろう。

\section{ダイキヤスト技術}

ダイキャストの発展が長年月を要した一つの原因とし てダイキャスト業者自体の技術習得の点が挙げられる。 此の問題はダイキャスト鋳型の設計と製作及びダイキャ スト鋳造技術に分けられる。

\section{鋳 型の 設 計}

鋳型の設計は多くの場合要求者の提示する鋳物の青写 真によつて或は又特殊な場合は見本品によつてなされる

先ず第一に其の鋳物に最方適当なダイキャスト機械の 決定である。之れは説明するまでもない。

次に第二には鋳型の分割面 (Parting Line) を決定す る。之れはダイキャスト製品を可動型 (Ejector Die) の中に留まらしめそれを無理なく鋳型より押出すこと と、トリミング（湯口、鋳純などを取り除く作業）作業 を容易に簡単ならしむるために最も重大な根本的なもの である。又之れはダイキャスト製品の良否に最後まで関 係があるから設計技術者の知識と過去の経験を充分に働 かして最適な線を決定する必要がある。

第三に鋳物内部組織の完全なもの（Soundness）をダ イキャストするため頶射口（Sprue）湯路 (Runner) 湯 口 (Gate)の位置決め(Location)である。之れも鋳物の 一つ一つによつて全く異つて来るので現在の処仲々計算 通りにはゆかない。殊に湯口の形状、寸法が難かしい。

第四は中子の位置、方向の決定であるが、鋳物の形状 が極めて簡単で可動型と固定型で造形し得るようなるの は此の設計は不要であり、又単純な中子で済む場合は問 題はないが複雑で或る角度を持った可動中子を必要とす る場合はそれの決定及び稼動方法、装置機構の決定等ダ イキャスト以外の方法には見られない困難さがある。

第五は寸法精度の確実な鋳物を作るため、指定寸法に 各種合金のシュリンケーヂを加算した鋳型寸法の計算、 決定がある。シュリンケーヂの率は合金の種類によつて 異るし又鋳物の各部分の肉厚、形状、湯口及びゥーリン グパイプの位置、中子の有無及びダイキャスト鋳造作業 のサイクル数によつても異つて来るのでダイキャスト作 業のあらゆる面をマスターした技術者でなければ正しい 嚴密な数値の決定は出来難い。

第六は鋳物に有害でなく而も鋳型より鋳物をスムース に押し出す位置に押出ピンの位置を決定ずる。之れは簢 単のようで実際にやって見ると難かしいものである。

第七は合金が鋳型内に注出されると同時に型䔰内の空 気やガスが鋳型外に排出され鋳物内部に空気孔やガス孔

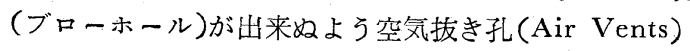
空気溜り翯の決定がある。

第八は連続せる鋳造作業中に鋳型が過熱され鋳物が出 来なくなるのを防止するため冷却装置 (Cooling)を施す が其の最も適当な位置決めがある。

其の他ダイキャスト作業に必要な特殊な点例えばイン
サート等の事項について考案する必要がある。

以上は順序をつけ個条書きに述べたが各項共総て関連 性があるので綜合的に設計方針が決められるがダイキャ スト製品は個々別々に全く異るので長年月の経験を必要 とする。

\section{鋳 型 の 製 作}

鋳型の製作は設計図面通りに機械加工或は手仕上げに て製作組立すればよいのであるが鉡物を鋳型よりスムー スに無晸で引出すためには各部に抜け公配を必要とする から、此の点に於ても充分な経験を必要とする。而も此の 拔け公配はシュリンケーヂと同じく各部によつて異る。

\section{ダイキヤスト鋳造技術}

諸外国では其の鋳型による鋳造に最も適当な一定の条 件を決定して置き、作業品は其の方針書通りに作業すれ ばよいことになつているそうである。我国でも一部の会 社では其の方釬を採用していると聞えているが一般には 其れまでになつていないのが普通である。そのため鋳型 の温度、注入合金の温度及び圧入速度、圧力の調節等或は 鋳型えの合金のカジリ付きの解決、湯嵧や湯界線の除去 タイスリックの使用程度など過去の経験に俟つものが数 多くある。特に軽合金のダイキャスト作業は亜鉛、錫合 金に比して上記の各点で困難が多いことを記して置く。

以上経験によることを強調したが我国のダイキャスト 業者も相当永い年月の経験を持つているのであるから之 れを科学的に分析研究して一つのデーターをを作成し将来 の大いなる発展の基楚になし得る現状に立ち至つている のである。

\section{アルミニウムダイキヤスト製品精度の問題}

之れについてはダイカスト技術委員会に於て標準的な ものを作成し、各使用者側に諒解されるよう努めている が、一般許容範囲と極限許容範囲との決定は仲々難かし い問題である。ダイキャスト業者は使用者側の製作する 機械部品を作るのであるから利用者と充分打合わせをな し又利用者もダイキャスト業者の意見を容れてより良い ダイキャスト製品を作るように協力すれば此の問題は解 決するものである。

\section{鋳型耐久度の問題}

従来はアルミニウムダイキャスト鋳型は耐久性が少な く一型で 8,000 〜10,000 個程度であると謂われていた か、クローム、モリブデン、バナジウム鋼が製作市販さ れ之れを加工後変形なく而もスケールの生ぜざるよう熱 処理することによつて10倍以上の耐久度を持つことが判 明している。之れは仲々細部に亘つては色々問題がある が今年辺りよりダイカスト技術委員会で其の解決に著手 しているから早晩解決されることである。

其の他ハードスポットの問題、アルミニウム合金の範 囲の問題、ダイキャスト機械の問題、製品加工方法の問題 等々軽合金ダイキャストについて頗る未解決のものが多 いのが現在の日本のダイキャストの現状である。之れを 以つて看るに我国の軽合金ダイキャストは今後の問題で あつて将来多いに其の発展を嘱目されてよいと思う。 